University of Cincinnati College of Law

University of Cincinnati College of Law Scholarship and

Publications

2000

The Problem of Obtaining Evidence for International Criminal Courts

Jacob Katz Cogan

Follow this and additional works at: https://scholarship.law.uc.edu/fac_pubs

Part of the Courts Commons, Criminal Law Commons, Human Rights Law Commons, and the International Law Commons 


\title{
The Problem of Obtaining Evidence for International Criminal Courts
}

\author{
Jacob Katz Cogan *
}

\begin{abstract}
International criminal courts will be judged by their fairness to defendants as well as to victims. In a very practical way, such claims will hinge, inter alia, on the ability of prosecutors and defendants to have reasonable access to probative evidence. But international criminal courts depend on states to provide them with evidence or access to evidence. The obligation of states to cooperate with international criminal tribunals in the production of evidence was at issue in the recent decision of the International Criminal Tribunal for the former Yugoslavia in the Blaškić case (1997). That judgment and the provisions of the Rome Statute of the International Criminal Court (1998) that address judicial assistance deserve investigation. Do the rules propounded in Blaškić and in the Rome Statute create the right conditions for the institution of fair trials in international criminal courts in our world today? Are such rules possible? The author argues that the diplomats in Rome failed to establish a procedure for the production of evidence that will lead to the goal of a fair and effective trial. This is cause for concern if and when an International Criminal Court comes into being.
\end{abstract}

\footnotetext{
* Jacob Katz Cogan is a law clerk to Judge Sandra Lynch, U.S. Court of Appeals for the First Circuit. He is a graduate of the University of Pennsylvania, Princeton University, and the Yale Law School. He would like to thank Brannon Denning, Katarina Grenfell, Karen Johnson, Sarah Lytle, Brent McIntosh, Michael Reisman, and Andrew Tauber for their helpful criticisms of earlier versions of this article.

1. The author served as a legal intern in the United Nations Office of Legal Affairs at the Diplomatic Conference of Plenipotentiaries on the Establishment of an International Criminal Court, where the Rome Statute of the International Criminal Court was adopted in July 1998. In no way does this article make use of any confidential information to which the author may have been privy, nor does it necessarily represent the views of the Office of Legal Affairs.
} 


\section{CONTENTS}

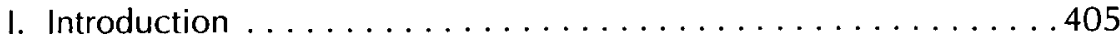

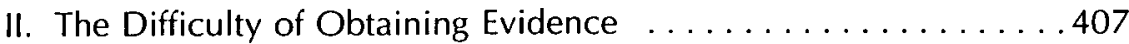

A. The Blaškić Case . . . . . . . . . . . . . . . . . . 407

B. What's at Stake ...................410

III. The Subpoena Power Asserted and Reassessed . . . . . . . . . 415

A. Blaškić I: Finding What You Are Looking For ........4415

B. Blaškić II: The Realistic Approach . . . . . . . . . . . .419

C. An Alternative Solution ...................422

IV. Blaškić and the Rome Statute ..................423

A. The Legacy of Blaškić ........................ 423

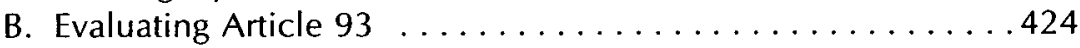

V. Conclusion: Fair Trials in International Criminal Courts? . . . . . .426

\section{INTRODUCTION}

International criminal courts will be judged by their fairness to defendants as well as to victims. In a very practical way, such claims will hinge, inter alia, on the ability of prosecutors and defendants to gain reasonable access to probative evidence. In domestic legal systems prosecutors have at hand the resources and the coercive powers of the state, subject to certain constitutional limitations, as they pursue leads and conduct investigations. In the international system no such procedures exist. When a state requires evidence that is in the possession of another state, it must resort either to already existing mutual legal assistance treaties or to diplomatic negotiations. ${ }^{2}$ When international criminal courts seek such cooperation, prosecutors and investigators must depend on states to provide them with evidence or access to evidence. ${ }^{3}$ Without such assistance, trials cannot go forward lest the legitimacy of the proceedings and, by extension, the court itself, be called into question. ${ }^{4}$

2. See David McClean, International Judicial Assistance (1992).

3. International courts are dependent on state cooperation in a host of other matters as well, including, most importantly, the arrest, detention, and transfer of indicted persons. A number of states have enacted statutes to facilitate cooperation with the International Criminal Tribunal for the Former Yugoslavia (ICTY) on these matters. See, e.g., Colin Warbrick \& Dominic McGoldrick, Current Developments in Public International Law: Co-operation with the International Criminal Tribunal for Yugoslavia, $45 \mathrm{INT}^{\prime} \mathrm{L}$ \& ComP. L.Q. 947 (1996) (reviewing the British statute).

4. The Tadic Court recognized this problem in the context of calling witnesses to testify, stating that it is "a difficulty encountered by both parties . . . [due to] their limited access 
The obligation of states to cooperate with international criminal tribunals in the production of evidence was at issue in the recent Blaškić case (1997) before the International Criminal Tribunal for the former Yugoslavia (ICTY). ${ }^{5}$ In Blaškić, the Appeals Chamber, reversing the ICTY's Trial Chamber, held that the ICTY did not have the power to issue subpoenas to states for evidence in their possession; the court could only issue non-coercive "binding orders." 6 That decision and the provisions of the Rome Statute of the International Criminal Court (1998) that address judicial assistance $^{7}$ deserve investigation. Do the rules propounded in Blaškić and in the Rome Statute create the right conditions for the institution of fair trials in international criminal courts in our world today? Are such rules possible? ${ }^{8}$

Part II of this article will introduce the problem of obtaining evidence for international criminal tribunals and will provide background on the

to evidence in the territory of the former Yugoslavia." The court decided, however, that the "steps . . . taken by the International Tribunal to assist the parties. . . . did appear to alleviate the inherent difficulties of the situation." Opinion and Judgment, Prosecutor $v$. Tadic, Case No. IT-94-1-T, T. Ch. II, III 530-31 (ICTY 7 May 1997), available at <http:/www.un.org/icty/tadic/trialc2/judgement-e/tad-tj970507e.htm> (visited 16 Feb. 2000) [hereinafter Tadic: Opinion and Judgment]. This aspect of the Trial Chamber's decision was one of the grounds for the defendant's appeal, which the Appeals Chamber recently rejected, endorsing the principle of "equality of arms" but rejecting the contention that the principle was violated in this case. Judgment, Prosecutor $v$. Tadic, Case Number IT-94-1, App. Ch., II 43-56 (ICTY 15 July 1999), available at <http://www.un.org/icty/tadic/appeal/judgement/tad-aj990715e.htm> (visited 16 Feb. 2000) [hereinafter Tadic: Appeals Chamber Judgement].

5. Decision on the Objection of the Republic of Croatia to the Issuance of Subpoenae Duces Tecum, Prosecutor v. Blaskic, Case No. IT-95-14-T, T. Ch. II (ICTY 18 July 1997), available at <http://www.un.org/icty/blaskic/trialc1/decisions-e/70718SP2.htm> (visited 16 Feb. 2000) [hereinafter Blaškic I].

6. Judgement on the Request of the Republic of Croatia for Review of the Decision of Trial Chamber II of 18 july 1997, Prosecutor v. Blaškić, Case IT-95-14-AR108bis, App. Ch., III 25-26 (ICTY 29 Oct. 1997), available at <http://www.un.org/icty/blaskic/appeal/ decision-e/71029JT3.html> (visited 16 Feb. 2000) [hereinafter Blaškic II]. As this article was going to press, the Trial Chamber found Blaškić guilty and sentenced him to fortyfive years in prison. See Prosecutor v. Blaškić, Judgment: Trial Chamber, Case IT-95-14T, 3 Mar. 2000 (visited 15 Mar. 2000), available at <http:/www.un.org/icty/blaskic/ trialcl/judgement/index-f.htm $>$. Unfortunately, I have been unable to include in this article a discussion of the court's decision.

7. Rome Statute of the International Criminal Court, opened for signature 17 July 1998 , U.N. Diplomatic Conf. of Plenopotentiaries on the Establishment of an $\operatorname{Int}^{\prime} \mid \mathrm{Crim}$. Ct., arts. 86-102, U.N. Doc. AVCONF.183/9 (1998), reprinted in 37 I.L.M. 999 (1998) [hereinafter Rome Statute].

8. The ICTY, to date, has confronted the question of fair trials most directly in connection with witness protection. See Sean D. Murphy, Progress and Jurisprudence of the International Criminal Tribunal for the Former Yugoslavia, 93 AM. J. INT'L L. 57, 83-84 (1999). See also Sara Stapleton, Note, Ensuring a Fair Trial in the International Criminal Court: Statutory Interpretation and the Impermissibility of Derogation, 31 N.Y.U. J. INT'L L. \& POL. 535 (1999). The court, however, has not spoken generally on the topic. But see Tadic: Appeals Chamber Judgment, supra note 4, II 55 ("The Appeals Chamber can conceive of situations where a fair trial is not possible because witnesses central to the defence case do not appear due to the obstructionist efforts of a State."). 
Blaškić case. Part III will discuss and evaluate the judgments of the Trial Chamber and the Appeals Chamber. ${ }^{9}$ I will argue that the Appeals Chamber, in its reversal of the lower court's ruling, pragmatically assessed the ICTY's limited coercive powers and the primacy of politics and policy when confronting states and their national security and sovereignty concerns. I will suggest, however, that the Appeals Chamber could have strengthened the Tribunal's ability to gather evidence by having made a narrower ruling that relied on the General Framework Agreement for Peace in Bosnia and Herzegovina ${ }^{10}$ and not the ICTY Statute" or the UN Charter. ${ }^{12}$ In Part IV, I will evaluate the provisions of the Rome Statute to determine if the realistic approach, which characterized the Appeals Chamber decision in Blaškić, is an appropriate template for the International Criminal Court (ICC). I argue that it is not. Instead, a teleological approach, ironically similar to that used by the Trial Chamber in Blaškić, would have made for a more effective ICC treaty. The Rome Statute, insofar as it conforms to the Appeals Chamber judgment in Blaškić, thus, is deficient. This being the case, 1 conclude in Part $V$ that it is unclear whether, in our day, the international community is prepared (or able) to give international criminal courts the resources necessary to obtain the evidence required to conduct fair trials.

\section{THE DIFFICULTY OF OBTAINING EVIDENCE}

\section{A. The Blaškić Case}

Tihomir Blaškić, an ethnic Croat, was born in Bosnia and Herzegovina in 1960, was graduated from the Belgrade Military Academy in 1983, and was

9. To date, there has been only limited discussion of the Blaškić Case in the scholarly literature. See, e.g., Murphy, supra note 8, at 81-82; Yves Nouvel, Précisions sur le pouvoir du Tribunal pour l'ex-Yugoslavie d'ordonner la production des preuves et la comparution des témoins: L'Arrêt de la Chambre d'appel du 29 octobre 1997 dans I'affaire Blaškić, 102 Revue Générale de dROIT INTERNational PUbuic 157 (1998); Göran Sluiter, Obtaining Evidence for the International Criminal Tribunal for the Former Yugoslavia: An Overview and Assessment of Domestic Implementing Legislation, 45 NETH. INT'L L. Rev. 87, 90-91 (1998); Anne Bodley, Note, Weakening the Principle of Sovereignty in International Law: The International Criminal Tribunal for the Former Yugoslavia, 31 N.Y.U. J. INT'L L. \& Pol. 417, 459-68 (1999).

10. General Framework Agreement for Peace in Bosnia and Herzegovina, U.N. Doc. S/ 1995/999 (1995), reprinted in 35 I.L.M. 75 (1996) [hereinafter General Framework Agreement].

11. Statute of the International Tribunal for the Prosecution of Persons Responsible for Serious Violations of International Humanitarian Law Committed in the Former Yugoslavia Since 1991, U.N. SCOR, Annex, U.N. Doc. S/25704 (1993), reprinted in 32 I.L.M. 1159, 1192 (1994) [hereinafter ICTY Statute].

12. U.N. Charter, signed 26 June 1945, 59 Stat. 1031, T.S. No. 993, 3 Bevans 1153 (entered into force 24 Oct. 1945). 
commissioned a second lieutenant in the Yugoslav People's Army that same year. ${ }^{13}$ Upon the disintegration of Yugoslavia, Blaškić joined the Croatian Defense Council (HVO) of the Croatian Community of Herceg-Bosna in Bosnia. ${ }^{14}$ By 1992 he had achieved the rank of colonel and commander of the Central Bosnia Operative Zone of the HVO, and by August 1993 he held the rank of general and was the HVO chief of staff. ${ }^{15}$ It was during this period that the HVO, anticipating the partition of Bosnia, expelled Bosnian Muslims from their homes in Croatian controlled territory, massacring some, while placing others in concentration camps. ${ }^{16}$ Two years later, on 10 November 1995, Richard J. Goldstone, then chief prosecutor of the ICTY, ${ }^{17}$ issued an indictment for Blaškić and five other members of the HVO for crimes against humanity and grave breaches and violations of the laws of war arising out of their command responsibility. ${ }^{18}$ Blaškić is one of the highest-ranking military officials to be tried to date. ${ }^{19}$

13. See Indictment, Prosecutor v. Kordić, Case No. IT-95-14-I, II 3 (ICTY 2 Nov. 1995), available at <http://www.un.org/icty/indictment/english/bla-ii951110e.htm> (visited 16 Feb. 2000) [hereinafter Blaškić Indictment]. The Croatian Association of Former Prisoners in Serbian Concentration Camps has sponsored an Internet site on the Blaškić case that details his biography and his defense strategy. Croatian Association of Former Prisoners in Serbian Concentration Camps, Tihomir Blaškić at the "International Criminal Tribunal for former Yugoslavia" -A Prosecution (visited 16 Feb. 2000) <http:// jagor.srce.hr/zatocenici/blaskicen.htms.

14. See Blaškić Indictment, supra note 13. For background to the Bosnian war, see, amongst numerous writings, Wayne Bert, The Reluctant Superpower: United States' Policy in Bosnia, 1997-1995 (1997); Norman Cigar, Genocide in Bosnia (1995); Robert J. Donia \& Johin V.A. Fine, Jr., Bosnia \& Hercecovina: A Tradition Betrayed (1994); Misha Glenny, The Fall of Yugoslavia: The Thiro Balkan War (1994); Noel Malcolm, Bosnia: A Short History (1994); Mass Rape: The War against Women in Bosnia-Herzegovina (Alexandra Stiglmayer ed., 1994); David Rieff, Slaughterhouse: Bosnia and the Fallure of the West (1995); David Rohde, Endocame: The Betrayal and Fall of Srebrenica, Europés Worst Massacre Since World War II (1997).

15. See Blaškić Indictment, supra note 13 , II 3.

16. See CIGAR, supra note 14 , at $125-26$.

17. On the creation of the ICTY and the prosecution of its first trial, see Michael. P. SCharf, Balkan justice (1997). See also The Prosecution of International Crimes (Roger Clark \& Madeleine Sann eds., 1996). There are two published compilations of documents related to the establishment and functioning of the ICTY: M. Cherif Bassiouni \& Peter Manikas, The Law of the International Criminal Tribunal for the Former Yugoslavia (1996); Vircinia Morris \& Michael P. Scharf, An Insider's Guide to the International Criminal Tribunal fOr the Former Yucoslavia (1995).

18. See Blaškić Indictment, supra note 13, II 11 35-38. The Blaškić indictment has been amended twice. Amended Indictment, Prosecutor v. Blaškić, Case No. IT-95-14-PT, T. Ch. I (ICTY 15 Nov. 1996), available at <http://www.un.org/icty/indictment/english/ bla-1 ai961122e.htm> (visited 16 Feb. 2000); Second Amended Indictment, Prosecutor v. Blaškic, Case No. ICTY-95-14-PT, T. Ch. I (ICTY 25 Apr. 1997), available at <http:// www.un.org/icty/indictment/english/bla-2ai970425e.htm> (visited 16 Feb. 2000).

19. See Robert Marquand, Bosnia Trial Shows Court's Rising Clout, Christian SCI. Monitor, 1 Oct. 1997, at 6. 
On 15 January 1997, at the request of the Office of the Prosecutor, ${ }^{20}$ Gabrielle Kirk McDonald, ${ }^{21}$ the American trial judge in charge of the Blaškić case, issued subpoenae duces tecum to the Republic of Croatia, the Croatian Defense Minister Gujko Šušak, the Federation of BosniaHerzegovina, and the Custodian of the Records of the Central Archive of the Ministry of Defense of the Croatian Community of Herceg-Bosna. ${ }^{22}$ Croatia immediately challenged the subpoenas, arguing that the ICTY had no authority to issue coercive orders to states and high government officials and that, even if the ICTY had such powers, a state still had the right to limit its compliance in order to protect its national security interests. ${ }^{23} \mathrm{~A}$ series of hearings ensued that led to the confirmation of the subpoena by a three-judge Trial Chamber panel in July $1997^{24}$ and then its quashing by the Tribunal's Appeals Chamber the following October. ${ }^{25}$

20. The timing of the subpoenas was curious, as it came on the eve of the trial, which had already been postponed once before.

21. Judge McDonald began her career as a civil rights lawyer and was appointed by President Jimmy Carter to the federal bench in 1979. She was one of the first judges appointed to the ICTY in 1993. After serving as a member of the Trial Chamber, Judge MCDonald was made a member of the Appeals Chamber and President of the ICTY. She retired in the fall of 1999. See Marlise Simons, Then It Was the Klan, Now It's the Balkan Agony, N.Y. Times, 13 Jan. 1999, at A4; James Walsh, "I'm Kind of A Crusader": With the First Bosnian War-Crimes Sentence, Judge Gabrielle McDonald Vents Her Passion for Justice, Time (int'l ed.), 28 July 1997, at 38, available in 1997 WL 10902692.

22. The Subpoena Duces Tecum to the Republic of Croatia directed Defense Minister Gojko Šušak to provide, inter alia,

[a]ll directives and orders, signed and unsigned, directed to Tihomir Blaškićl, . . . [a]ll orders, communications and directives, signed and unsigned, directed to Mate Boban, the General Staff of the HVO and the Ministry of Defense of the Croatian Community of Herceg Bosna and its representatives, ... from 1 April 1992 to 1 January 1994l, and] [a]ll Croatian government Ministry of Defense documents, records, reports and orders reflecting the presence of HV military personnel and their activities in the Republic of Bosnia and Herzegovina from November 1991 to 1 July 1994....

Subpoena Duces Tecum to the Republic of Croatia, Prosecutor v. Blaškić, Case No. IT-95-14-T, Judge MCDonald (ICTY 15 Jan. 1997) (Registry Page no. (RP) D488-93).

23. Paragraph 1 of the Brief of the Republic of Croatia on Subpoenae Duces Tecum provides that: "It is the position of the Croatian Government that a subpoena duces tecum, as an order issued 'under penalty,' has no legal grounds as a form of communication between the Tribunal and sovereign States and their government officials." Brief of the Republic of Croatia on Subpoenae Duces Tecum, Prosecutor $v$. Blaškić, T. Ch. II, Case No. IT-95-14-PT, I 1 (ICTY 1 Apr. 1997) (RP D3682-84); Republic of Croatia, Reply to Subpoena Duces Tecum, Prosecutor v. Blaškić, Case No. IT-95-14-PT, T. Ch. I (ICTY 10 Feb. 1997) (RP D3261-63).

24. See Blaskić I, supra note 5.

25. See Blaškić II, supra note 6 . 


\section{B. What's at Stake}

For a procedural matter, the subpoena issue garnered a great deal of attention from the international legal community. No fewer than five countries, seven individuals, two international organizations, and one Croatian professional association submitted amicus curiae briefs to the various proceedings. ${ }^{26}$ In the months following the Appeals Chamber judgment, as the Rome Conference on the Establishment of an International Court neared, national delegations and NGOs took additional interest in the case. ${ }^{27}$ It is not difficult to understand why.

The importance of the issue for the ICTY is clear: criminal courts require evidence to determine the guilt or innocence of the accused. "I am aware that Blaškić is one of the most, if not the most important case, I will ever try," Chief Prosecutor Louise Arbour noted a month before the Appeals Chamber handed down its judgment. ${ }^{28}$ "The issues have everything to do with the coming of age of the tribunal as a criminal court. It is the first time in history we are putting this question to the test: Can international law apply in the area of criminal law?"29 Blaškić's defense attorney was no less interested. "[l]f the court can't request records, then I can't defend my client," Russell Hayman pointed out. ${ }^{30}$ Without such evidence, the prosecutors in The

26. See id. II 17 (noting that China, the Netherlands, Canada and New Zealand, Norway, Ruth Wedgwood, Max Planck Institute for Foreign and International Criminal Law, Juristes sans frontières and Alain Pellet, Carol Elder Bruce, and Herwig Roggemann submitted amicus curiae briefs); Blaškić I, supra note 5, II 10 (noting that the following were given leave to submit amicus briefs to the Trial Chamber: Bruno Simma, Bartram Brown, the Croatian Association of Criminal Science and Practice, the Lawyers Committee for Human Rights, Juristes sans frontières, Luigi Condorelli, the Max Planck Institute for Comparative Public Law and International Law, Peter Malanczuk, Juan-Antonio Carrillo Salcedo, Thomas Warrick et al., Ruth Wedgwood, and Annelisa Ciampri). See also Order Granting Leave to Appear as Amicus Curiae [Various], Prosecutor v. Blaškić, Trial Chamber, Case No. IT-95-14-PT, T. Ch. II (ICTY 11 Apr. 1997), available at <http://www.un.org/icty/blaskic/orde14.htm> (visited 16 Feb. 2000) (inviting, among others, Juristes sans frontières, Luigi Condorelli, the Croatian Association of Criminal Science and Practice, Andreas Zimmermann, Ruth Wedgwood, Marie-josé Domestici-Met, Peter Malanczuk, and the Lawyers Committee for Human Rights to appear at oral argument). Of the permanent five members of the Security Council, only China submitted a brief in the case.

27. See infra note $\mathbf{9 8}$ and accompanying text.

28. Marquand, supra note 19, at 6 (quoting Arbour).

29. Id. (quoting Arbour). In a speech given before the Appeals Chamber decision, she stated: "I believe this may be the single most important issue that I will have to address in my term of office as Chief Prosecutor. ... This is an absolutely critical phase in the development of the ICTY." Louise Arbour, The Status of the International Criminal Tribunals for the Former Yugoslavia and Rwanda: Goals and Results, 3 Hofstra L. \& PoL'Y SYMP. 37, 38 (1999).

30. Marquand, supra note 19, at 6 (quoting Hayman). See also Tracy Wilkinson, Reason to Take on War Crimes, L.A. Times, 15 May 1998, at A1. 
Hague are at a huge disadvantage when called upon to meet their burden of proof; the defense counsel are under similar constraints.

States, however, are under no general obligation to release evidence within their jurisdiction, and the Tribunal itself has no mechanism to enforce its will upon states. As the court recognized in its first annual report in 1994, "the Tribunal was not endowed with direct enforcement powers." ${ }^{31}$ In contrast to Nuremberg, ${ }^{32}$ where the problem of obtaining evidence was never an issue because the Allies had unhampered access to the German archives, the ICTY, "[t]o fulfil all [its] tasks, . . must rely upon the domestic legal system and the enforcement machinery of each State." ${ }^{\prime 3}$ The difficulty of obtaining evidence, accordingly, is nowhere more complicated than in the former Yugoslavia, where the alleged crimes were often conducted by (or under instructions from) state actors and where the evidence of these crimes remains within the jurisdiction of interested parties. ${ }^{34}$ When the accused is charged with crimes emanating from his command responsibility, as in Blaškić, states are highly resistant to disclosing evidence that might inculpate one of their own. But it is especially in these types of cases, where the chain of command must be established, that prosecutors are most in need of evidence from a state's military archives. ${ }^{35}$ In Bosnia, while the Implementation Force (IFOR) has facilitated the investigative work of the Office of the Prosecutor in territory under IFOR control, ${ }^{36}$ much of the most

31. Annual Report of the International Tribunal for the Prosecution of Persons Responsible for Serious Violations of International Humanitarian Law Committed in the Territory of the Former Yugoslavia since 1991, U.N. GAOR, 49th Sess., Provisional Agenda Item 152, II 84, U.N. Doc. A49/342-S/1994/1007, at 3, 27 (1994) thereinafter First Annual Report].

32. According to Kenneth Anderson, "[T]hose who want to imitate Nuremberg in Yugoslavia have deeply mistaken what the Nuremberg trial was all about. At its core Nuremberg was about foregoing what was in one's hand; this Yugoslavia tribunal wants to grasp what the world has not been willing to put there." Kenneth Anderson, Nuremberg Sensibility: Telford Taylor's Memoir of the Nuremberg Trials, 7 Harv. Hum. RTs. J. 281, 293 (1994) (book review).

33. First Annual Report, supra note 31, II 84.

34. See Steven R. Ratner \& Jason S. Abrams, accountability for Human Rights atrocities in International Law: Berond the Nuremberc Legacy 225 (1997).

35. "Prosecutors require more than names of military commanders or even witness accounts about cruelty and killing. To build their case against commanders, they need to link those responsible for crimes directly to the events and to present proof of who gave orders and who knew about atrocities." Marlise Simons, Court Calls for Evidence, Not Politics, N.Y. TIMes, 9 Apr. 1999, at A11.

36. See Fifth Annual Report of the International Tribunal for the Prosecution of Persons Responsible for Serious Violations of International Humanitarian Law Committed in the Territory of the former Yugoslavia Since 1991, U.N. GAOR, 53rd Sess., II 123, U.N. Doc. A/53/219-S/1998/737 (1998) ("Productive working relationships with organizations in the former Yugoslavia continues to be crucial to the success of the Prosecutor's investigations."). IFOR is now assisting the war crimes investigators in their work in Kosovo. See Marlise Simons, Crisis in the Balkans: War Crimes Investigators Prepare for 
important evidence remains outside of Bosnia-in Croatia, Serbia, and in Western security archives. In Blaškić, prosecutors, stymied by their inability to garner evidence essential to their case, seized upon the subpoena.

Prosecutors also sought the subpoena in order to alleviate the persistent problem of the uneven and instrumental provision of evidence by states. When asked if the United States had provided the ICTY with all the information it had available, Richard Goldstone lamented that "[i]t's impossible to know without knowing everything they have. ${ }^{\prime \prime 3}$ A state might try to influence the outcome of a trial by providing the Tribunal with only partial access to evidence it has in its possession. A state might also time the release of its evidence to suit its own purposes. So, for instance, even though Britain recently said it would provide the ICTY with evidence relating to possible war crimes by Yugoslav President Slobodan Milosevic, one can ask, as Goldstone did, "whether the information now being offered wasn't available two, three, or four years ago ?"38 Certainly some of it was and the reason for Britain's newly found generosity in the case of Milosevic is no great secret: previously, Britain, together with the United States and other countries, had decided that Milosevic, despite his crimes, was an important player in the peaceful settlement of the Bosnian crisis. Now that Milosevic is persona non grata for his actions in Kosovo, the West is willing to provide evidence crucial to his indictment and prosecution. As Michael Posner of the Lawyers Committee for Human Rights put it, "[Cooperation is] like a spigot. . . [States] want to turn it on and off as it suits their purposes." 39

But if the subpoena power is important for the successful investigation and prosecution of cases before the ICTY, there are countervailing considerations as well. If the Appeals Chamber were to have upheld the subpoena in Blaškić, future subpoenas no doubt would have been issued to Serbia to determine the role of the Yugoslav Army in the Bosnian conflict. ${ }^{40}$ More importantly, what would have stopped a Trial Chamber from issuing a subpoena to a national intelligence agency not directly party to the dispute,

Kosovo, N.Y. Times, 7 June 1999, at A11 ("Britain has offered to escort investigators as its troops enter Kosovo to help them start their inquiries immediately. . . . [Prosecutor Arbour] has also asked some NATO members to fly special missions with the unmanned reconnaissance planes known as drones in order to collect information of value for the tribunal. ...").

37. Raymond Bonner, Crimes Court Not Ready to Punish Kosovo Violence, N.Y. Times, 31 Mar. 1999, at A11 (quoting Richard Goldstone).

38. Id.

39. Id. (quoting Michael Posner). Cf. Raymond Bonner, Despite Indictment, Politicians and Diplomats Control Milosevic's Future, N.Y. TIMEs, 28 May 1999, at A13 (pointing out that, despite Milosevic's indictment, the ICTY is still dependent on states to apprehend him).

40. See Marquand, supra note 19 , at 6 . 
such as the CIA, which repeatedly has been accused of not sharing all the documents in its possession that are relevant to the ICTY's investigations? ${ }^{21}$ In all likelihood, most of these subpoenas would never be complied with and, in the case of the United States, they would put the ICTY in direct conflict with an important and essential backer. The ICTY's legitimacy as a court and perhaps its future existence might be put in peril by such sweeping subpoena powers. The court would be damned if it did (risking non-compliance by a major benefactor) and damned if it didn't (leading to charges of bias if it failed to issue subpoenas to national security agencies that retained evidence indispensable to the prosecution or the defense). Furthermore, to the extent that a state's (say, the United States) uneven provision of evidence to the ICTY is, in fact, a symptom of its attempt to come to a peaceful solution of an international conflict, we might be less sanguine about the court's exercising strong subpoena powers. ${ }^{42}$ While it is clear why the ICTY prosecutors were so eager to make use of the subpoena power in Blaškić and why they believed that that power is so crucial to the effective prosecution of the war crimes in the former Yugoslavia, it is less clear whether giving this power to the Tribunal is in the best interests of the ICTY or of the implementation of humanitarian law generally.

The Appeals Chamber's decision also had implications well beyond the ICTY. Not so subtly hidden under the debate in Blaškić was the movement for the creation of an ICC. ${ }^{43}$ Long favored by human rights advocates, ${ }^{44}$ the

41. See Bonner, supra note 37, at A11 (reporting that "[u]ntil now Western Governments have been disinclined to share their intelligence information"); Raymond Bonner, War Crimes Panel Finds Croat Army 'Cleansed' Serbs, N.Y. Times, 21 Mar. 1999, at A1 (reporting that "the United States has failed to provide critical evidence requested by the tribunal" so that its involvement in the Balkan war might remain concealed).

42. The ICTY's indictment of Slobodan Milosevic in the midst of the Kosovo air campaign raised similar concerns. Might not the ICTY's actions hamper attempts to end the conflict? See Jane Perlez, Some Fears Over Talks; Aides Worry, N.Y. Times, 28 May 1999, at A10. In all likelihood, however, the Milosevic indictment was issued with the prior tacit consent of Western governments, upon whom the ICTY would have been reliant for evidence to support its accusations. See also Bonner, supra note 37, at A11, and accompanying text.

43. For some selected recent histories and appraisals of the idea of an international criminal court, see M. Cherif Bassiouni, From Versailles to Rwanda in Seventy-Five Years: The Need to Establish a Permanent International Criminal Court, 10 Harv. Hum. RTs. J. 11 (1997); Christopher L. Blakesley, Obstacles to the Creation of a Permanent War Crimes Tribunal, 18 Fletcher F. on Worlo Aff. 77 (1994); John W. Bridge, The Case for an International Court of Criminal Justice and the Formulation of International Criminal Law, in International Courts for the Twenty-First Century 213 (Mark W. Janis ed., 1992); John Dugard, Obstacles in the Way of an International Criminal Court, 56 CAmbrideE L.J. 329 (1997); Timothy C. Evered, An International Criminal Court: Recent Proposals and American Concerns, 6 PACE INT'L L. Rev. 121 (1994); Paul D. Marquardt, Law Without Borders: The Constitutionality of an International Criminal Court, 33 Colum. J. TransNAT'L L. 73 (1995); Michael P. Scharf, The Politics of Establishing an International Criminal Court, 6 Duke J. Comp. \& INT'L L. 167 (1995); Leila Sadat Wexler, The Proposed 
plan for an ICC received increasing political support during the $1990 \mathrm{~s}^{45}$ culminating in the Rome Conference on the Establishment of an International Criminal Court in 1998. Rightly or wrongly, the actions of the ICTY will be perceived as a benchmark for the creation and future operation of the new court. ${ }^{46}$

In no area will this be truer than procedure, where little has been developed since the Nuremberg trials fifty years ago. ${ }^{47}$ The ICTY Statute gave the judges the power to "adopt rules of procedure and evidence." ${ }^{\prime 48}$ And, as Judge McDonald admitted at an academic conference in August 1997, referring to the ICTY, "We basically created an international code of criminal procedure." ${ }^{49}$ Any decision of the court interpreting the ICTY's rules is bound to have important consequences for a future ICC, for which

Permanent International Criminal Court: An Appraisal, 29 Connell INT'L L.J. 665 (1996); Alex C. Lakatos, Note, Evaluating the Rules of Procedure and Evidence for the International Tribunal in the Former Yugoslavia: Balancing Witnesses' Needs Against Defendants' Rights, 46 Hastings L.J. 909 (1995). For a useful collection of documents, see Beniamin B. Ferencz, An International Criminal Court: A Step Toward World Peace-A Documentary History and Analysis (1980).

44. According to one estimate, over three hundred human rights and legal reform associations, including the American Bar Association, have argued in favor of an ICC. See Douglas W. Cassel, Jr., A New International Criminal Court: Will It Be Independent?, ChI. Dally L. Butl., 9 Mar. 1998, at 6; World Criminal Court: All Gum, No Teeth?, ECONOMist (London), 14 Mar. 1998, at 50. Many of these NGOs have banded together to form the Coalition for an.International Criminal Court. See The CICC International Criminal Court Home Page (visited 10 Feb. 2000) <http:/www.igc.org/icc>.

45. See Wexler, supra note 43, at 666 n.6. Samantha Power points out, however, that "while national governments usually choose to forego retributive justice [in favor of truth commissions], outsiders (including the United States) are formally swearing by it." Samantha Power, The Stages of Justice, New Repubuc, 2 Mar. 1998, at 38, 39 (reviewing Mark Osiel, Mass Atrocity, Collective Memory, and the Law (1998)).

46. According to Morris and Scharf: "If the International Tribunal demonstrates that such an institution can function effectively and efficiently, then the case for establishing a permanent court will be strengthened beyond measure." MORRIS \& SCHARF, supra note 17 , at 354. See also Danesh Sarooshi, The Powers of the United Nations International Criminal Tribunals, 2 Max PLANCK Y.B. U.N. L. 141, 167 (1998). Jelena Rejic argues, however, that "the emerging profile of an ICC is so different from that of the ad hoc Tribunal that the very notion of the latter's success as being critical to the former may be called into question." Jelena Pejic, The Tribunal and the ICC: Do Precedents Matter?, 60 AlB. L. ReV. 841 (1997).

47. See Morris \& SChARF, supra note 17, at 175. According to James Crawford, however, "[r]ather stringent standards have been laid down in international human rights treaties, regulating due process in criminal trials." James Crawford, The ILC Adopts a Statute for an International Criminal Court, 89 Aм. J. INT'L L. 404, 407 (1995). See generally Richard May \& Marieke Wierda, Trends in International Criminal Evidence: Nuremberg, Tokyo, the Hague, and Arusha, 37 Colum. J. Transnat'L L. 725 (1999).

48. ICTY Statute, supra note 11 , art. 15.

49. Barbara Crossette, World Criminal Court Having Painful Birth, N.Y. Times, 13 Aug. 1997, at $\mathrm{A} 10$ (quoting Judge McDonald). 
new Rules of Procedure and Evidence are currently being negotiated.$^{50}$ It is to Blaškić, the most important ICTY decision to date on the rules of evidence that we now turn.

\section{BLAŠKIĆ: THE SUBPOENA POWER ASSERTED AND REASSESSED}

The importance of the subpoena power to the ICTY and to a future ICC was foremost in Judge McDonald's mind when she wrote the Trial Chamber opinion in Blaškić. ${ }^{51}$ But in her attempt to achieve the laudable goal of an effective tribunal, Judge McDonald overreached. Her judgment would have allowed a Trial Chamber to issue subpoenas to all states; the issue in Blaškić, however, was more limited. Could the court issue a subpoena to the Republic of Croatia, one of the parties to the dispute in the former Yugoslavia? Confronted with Judge McDonald's broad ruling, the Appeals Chamber wisely retreated from the Trial Chamber's judgment. It recognized the ability of the court to issue only what it termed "binding orders" to states. As I will argue, however, if Judge McDonald had written a narrower opinion based upon the text of the General Framework Agreement that ended the Bosnian War, the Appeals Chamber would, in all likelihood, have upheld the subpoena in Blaškić. The larger, and more problematic issue of whether the ICTY could issue subpoenas to states not party to the Bosnia conflict could have been avoided.

\section{A. Blaškić I: Finding What You Are Looking For}

Judge McDonald's decision was based on a theory of "inherent" and "expressed" powers, as well as a comparison with the subpoena powers of national courts and other international judicial bodies. Judge McDonald

50. This is true not simply for precedential reasons but also because many of the players that created the ad hoc tribunals are also behind the creation of the ICC. See Peter Burns, An International Criminal Tribunal: The Difficult Union of Principle and Politics, 5 CRIM. L.F. 341, 350-51 (1994). For one of the few scholarly investigations of a procedural aspect of the ICTY, see Mark Thieroff \& Edward A. Amley, Ir., Proceeding to Justice and Accountability in the Balkans: The International Criminal Tribunal for the Former Yugoslavia and Rule 61, 23 YALE J. INT'L L. 231 (1998).

51. Judge McDonald suspended the subpoena on 19 Feb. 1997 in order to allow the parties to resolve the matter informally. That having failed, Judge McDonald ordered that the matter be heard by the full Trial Chamber. See Blaškić l, supra note 5, qा 1 2-12 (recounting the procedural history leading up to the Trial Chamber's decision). See In the International Criminal Tribunal for the Former Yugoslavia in the Trial Chamber (visited 16 Feb. 2000) <http://www.un.org/icty/transe14/9704161T.txt> (providing an unpaginated transcript of the oral arguments) [hereinafter Oral Argument]. 
looked first to Article 29 of the UN Charter, which states that "[t]he Security Council may establish such subsidiary organs as it deems necessary for the performance of its functions." ${ }^{52}$ McDonald found that "subsidiary organs may be empowered to perform the functions of the Security Council even to the extent that this may have external consequences." 53 Thus, Judge McDonald concluded that the ICTY, as a Security Council subsidiary organ established under Chapter VII of the UN Charter, ${ }^{54}$ is an independent international court. ${ }^{55}$

As an international court, McDonald argued, the ICTY retained certain inherent powers. Following the line of arguments made in the Prosecutor's brief, ${ }^{56} \mathrm{McD}$ onald found that "the International Tribunal should be deemed to have those powers which, although not expressly conferred, arise by necessary implication as being essential to the performance of its duties." ${ }^{57}$ Because compelled production of evidence was "part of the inherent powers of a judicial organ," 58 and because the Security Council intended that the ICTY be effective, McDonald concluded that the subpoena power, though not expressly granted, may be implied. ${ }^{59}$ Thus, "an order or

52. U.N. ChARTER art. 29.

53. Blaškić l, supra note 5, Il 20 (quoting The Charter of the United Nations: A Commentary 486 (Bruno Simma ed., 1994) (commentary by Meinhard Hilf)).

54. Article $\mathbf{4 1}$ of the UN Charter states: "The Security Council may decide what measures not involving the use of armed force are to be employed to give effect to its decisions, and it may call upon the Members of the United Nations to apply such measures. . .." U.N. CharTer art. 41. See also Danesh Sarooshi, The Legal Framework Governing United Nations Subsidiary Organs, 64 BRIT. Y.B. INT'L L. 422 (1996) (delineating the authority of the principal organs of the United Nations to create subsidiary organs).

55. See Blaškić l, supra note 5, II II 17, 23.

56. See Prosecutor's Brief in Support of Subpoenae Duces Tecum, Prosecutor v. Blaškić, Case No. IT-95-14-PT, T. Ch. II (ICTY 1 Apr. 1997) (RP D3620-3671) (setting out a theory of inherent and express powers). Paragraph 3 of the Amicus Curiae Brief states:

The Statute does not expressly confer upon the Tribunal the capacity to address subpoenas orders; however, the Tribunal must be deemed under International Law to have those powers which, though not expressly provided in the Statute, are conferred upon it by necessary implication as being essential to the performance of its duties.

Amicus Curiae Brief Presented by Professor Juan-Antonio Carrillo Salcedo, Prosecutor $v$. Blaškić, Case No. IT-95-14-PT, T. Ch. II, at 4 (ICTY 5 Apr. 1997) (RP D4660-72).

57. Blaškić l, supra note 5, II 24.

58. Id.

59. The court relied on language in the following decisions of the International Court of Justice: Reparations for Injuries Suffered in the Service of the United Nations, 1949 I.C.J. 171,182 ("Under international law, the Organization must be deemed to have those powers which, though not expressly provided in the Charter, are conferred upon it by necessary implication as being essential to the performance of its duties."); Effect of Awards of Compensation Made by the United Nations Administrative Tribunal, 1954 I.C.J. 47, 57 ("Capacity to do this arises by necessary intendment out of the Charter."); Certain Expenses of the United Nations, 1962 I.C.J. 151, 168 ("But when the Organization takes action which warrants the assertion that it was appropriate for the fulfillment of one of the stated purposes of the United Nations, the presumption is that such action is not ultra vires the Organization."). 
subpoena for the production of evidence is appropriate where the fairness of the trial so requires." 60

Judge McDonald found further evidence of such implied powers in the abilities of national courts to issue subpoenas. The ICTY, according to her reading of the statute, ${ }^{61}$ could not have lesser powers to prosecute war crimes than national courts. ${ }^{62}$ After canvassing the powers of various national courts, she found that, because they all had subpoena powers (to varying degrees), so too must the ICTY. ${ }^{63}$

Judge McDonald also garnered textual authority to support her position. ${ }^{64}$ Article 18 of the ICTY Statute, she pointed out, gave the prosecutor the power to collect evidence and seek the assistance of the states. ${ }^{65}$ And Article 19 allowed judges to issue "orders as may be required for the conduct of the trial." ${ }^{\prime 66}$ In its application of these articles, Rule 54 of the ICTY's Rules of Procedure and Evidence explicitly stated that a judge, at the request of either party, "may issue such orders, summonses, subpoenas, warrants and transfer orders as may be necessary for the purposes of an investigation or for the preparation or conduct of the trial. ${ }^{\prime 67}$ From these textual and non-textual sources Judge McDonald concluded that the ICTY was capable of issuing orders to states and that such orders would not offend a state's sovereignty. ${ }^{68}$

To bolster her claim, Judge McDonald drew parallels to other international courts. She noted that the rules of the International Court of Justice (ICJ) give the IC] the power to "call upon" the parties to bring witnesses or

60. The Blaskić / decision notes that Article 20 of the statute directs the Trial Chamber to ensure that a trial is fair and expeditious ... [and that] Article 21, paragraph 4(e) provides that the accused shall be entitled "to examine, or have examined, the witnesses against him and to obtain the attendance and examination of witnesses on his behalf under the same conditions as witnesses against him."

Blaškic l, supra note 5 , II 32.

61. ICTY Statute, supra note 11, art. 9, II 2. Paragraph 35 of the Blaškić / decision notes "its capacity to obtain all the necessary documents for the adjudication of a case cannot be less than that of [national] courts." Blaskić l, supra note 5, II 35.

62. Here, she follows the line of argument put forward by the Prosecutor in oral argument:

In my submission, if nothing else, it lthe subpoena powerl would have to form part of the inherent powers of a criminal court. There would be no doubt that a mechanism would have to be designed by the court itself to allow it to get access to the evidence that is necessary for a fair disposition of the case.

Oral Argument, supra note 51.

63. Blaškić l, supra note 5, II $36-40$.

64. Id II 42.

65. See ICTY Statute, supra note 11, art. 18, II 2.

66. Id. art. 19, II 2.

67. ICTY R. Proc. \& Evid. 54. The ICTY Rules of Procedure and Evidence, as amended, are available on the Internet at <http://www.un.org/icty/basic/rpe/IT32_rev17con.htm> (visited 16 Feb. 2000).

68. Blaškić l, supra note 5, II $50-51$. 
produce evidence. ${ }^{69}$ While the ICJ had no power to compel the production of evidence, the Trial Chamber concluded that the ICI could draw a negative inference from non-compliance. ${ }^{70}$ The same was true, judge McDonald claimed, of the Court of Justice of the European Communities and the European Court of Human Rights. ${ }^{11}$ Judge McDonald concluded

that it is a familiar concept that States can be addressed by international tribunals for the purpose of production of documents in their possession, when such are necessary for an international judicial determination. While these other international tribunals cannot compel this production by States, they do have as an inducement the power to draw a negative inference. ${ }^{72}$

Judge McDonald was, she admitted, more concerned with the power "to compel the attendance of witnesses and the production of evidence" and less with "the consequences of non-compliance."73 Even so, the court recognized some limits on its subpoena power, including relevancy and specificity, ${ }^{74}$ and, most importantly, national security. While the Trial Chamber acknowledged the legitimacy of an assertion of national security, it decided that it was for the tribunal and not for the state to decide the scope and application of the privilege. Though international ${ }^{75}$ and national

69. Article 49 states: "The Court may, even before the hearing begins, call upon the agents to produce any document or to supply any explanations. Formal note shall be taken of any refusal." Statute of the International Court of Justice, art. 49, annexed to U.N. Charter, signed 26 June 1945, 59 Stat. 1031, T.S. No. 993, 3 Bevans 1153 (entered into force 24 Oct. 1945). Article 62(1) of the Rules of the International Court of Justice states: "The Court may at any time call upon the parties to produce such evidence or to give such explanations as the Court may consider to be necessary for the elucidation of any aspect of the matters in issue, or may itself seek other information for this purpose." I.C.J. Rules of Court, adopted $14 \mathrm{Apr}$. 1978, art. 62(1), available at <http://www.icj-cij.org/ icjwww/ibasicdocuments/ibasictext/ibasicrulesofcourt.html> (visited 16 Feb. 2000).

70. Blaškić I, supra note 5, II 53. It is unclear whether the Trial Chamber's assertion is in fact true. Article 49 of the IC] statute simply states that the court may take "formal note" of "any refusal" to comply with the court's request. There is no indication, either in the Statute or in the court's practice, that suggests that "formal note" is equivalent to "negative inference." Cf. W. Michael Reisman, Nuluty and Revision: The Revifw and Enforcement of International Judgments and Awards 593-603 (1971) (discussing the Rule in Parker's Case).

71. Blaškić I, supra note 5, q1 54 .

72. Id. II 56. Even if Judge McDonald's assertions were true, what good is a negative inference in a criminal tribunal where the subpoenaed party itself is not on trial?

73. Id. II 61 (citing ICTY Statute, supra note 11, art. 29). Paragraph 62 states, "The Trial Chamber considers that use of a subpoena does not necessarily imply the assertion of a power to imprison or fine, as it may in a national context" and suggests a range of "penalties" from "a note of non-compliance and reference of the matter to the Security Council . . to consideration of utilizing the inherent contempt power or that provided for in Rule 77 against individuals who fail to comply." Id. II 62 .

74. See Blaškić I, supra note 5, II 99-105 (reviewing limits that national courts place on the subpoena power).

75. See id. II 116-122 (discussing the Corfu Channel Case, the Godinez Cruz Case, and The Observer and the Guardian v. The United Kingdom, and finding them unhelpful). 
courts $^{76}$ have often recognized or accommodated the privilege (or have not penalized its assertion), ${ }^{77}$ and the national implementing legislation for the ICTY of a number of nations specifically reserved the privilege, ${ }^{78}$ the Trial Chamber stressed that the ICTY was created under Chapter VII of the UN Charter: "A unilateral right of a State to withhold information necessary for the proceedings on national security grounds would prejudice the capacity of the International Tribunal to ensure a fair trial." ${ }^{\prime 79}$ Not only would it be "contrary to the spirit and the language of the Statute and to the nature and purpose of the International Tribunal to permit a State to invoke, absolutely, a national security privilege, ${ }^{\prime 80}$ the ICTY itself, the court asserted, was in a position to be the best decision maker. ${ }^{81}$

Judge McDonald had her eyes on the prize: an effective ICTY that was capable of holding fair trials. Her judgment would have allowed the Trial Chamber to issue subpoenas to states, subject only to certain national security, specificity, and relevancy limitations. Her opinion, however, did not concern itself with the unique context in which international courts operate. On the contrary, Judge McDonald relied on analogies to domestic courts to justify the Trial Chamber decision. Such an opinion could not (and did not) stand for long.

\section{B. Blaškić II: The Realistic Approach}

The Decision of the Trial Chamber was immediately appealed to the Appeals Chamber. ${ }^{82}$ In its judgment, handed down on 29 October 1997, the

76. See id. III 124-26 (discussing the United States, Canada, Pakistan, Costa Rica, Germany, and the United Kingdom).

77. The International Court of Justice, in the Corfu Channel Case (U.K. v. Alb.), 1949 I.C.J. 4 , requested certain documents that

were not produced, the Agent pleading naval secrecy; and the United Kingdom witnesses declined to answer questions relating to them. It is not therefore possible to know the real content of these naval orders. The Court cannot, however, draw from this refusal to produce the orders any conclusions differing from those to which the actual events gave rise.

Id. at 32 .

78. See Blaskić I, supra note 5, II II 127-29.

79. Id. I 131.

80. Id. I 133.

81. That decision was not arbitrary however. When evaluating a national security claim, the trial court judge must consider two interests: "the interest in upholding the national security interest of a State and the interest in gaining access to the evidence critical to the prosecution or defence in cases relating to serious violations of international humanitarian law." Id. II 149.

82. The Appeals Chamber accepted review of the appeal on 29 July 1997, Decision on the Admissibility of the Request for Review by the Republic of Croatia of an Interlocutory Decision of a Trial Chamber (Issuance of Subpoenae Duces Tecum) and Scheduling Order, Prosecutor v. Blaškić, Case No. IT-95-14-AR108bis, App. Ch. (ICTY 29 July 
Appeals Chamber evidenced a starkly different approach from that of the Trial Chamber. Whereas the lower court had analogized the powers of the ICTY to those of national courts, the higher court held that "domestic judicial views or approaches should be handled with the greatest caution at the international level, lest one should fail to make due allowance for the unique characteristics of international criminal proceedings. ${ }^{183}$

The Appeals Chamber began by finding that a subpoena, by which it meant an order "the non-compliance with which may be 'sanctioned' as contempt of court," ${ }^{14}$ could not be issued to states. "Had the drafters of the Statute intended to vest the International Tribunal with such a power," the court noted, "they would have expressly provided for it." ${ }^{85} \mathrm{~A}$ subpoena was not an inherent function of an international judicial body, as the Trial Chamber had concluded. ${ }^{86}$ Therefore, only orders or requests could be addressed to states. ${ }^{87}$ The binding force of such orders "derives from the provisions of Chapter VII and Article 25 of the United Nations Charter and from the Security Council resolution adopted pursuant to those provisions." ${ }^{\prime 88}$

What were the proper legal remedies for a state's non-compliance with a binding order? The Tribunal could only make judicial findings of non-compliance..$^{89}$ It was for the Security Council alone to impose sanctions if it so desired..$^{90}$ The Tribunal could not, however, issue subpoenas or even

1997), and refused to set aside this decision on August 12. Decision on Prosecution Motion to Set Aside the Decision of the Appeals Chamber of 29 July 1997, Prosecutor v. Blaškić, Case No. IT-95-14-AR108bis, App. Ch. (ICTY 12 Aug. 1997). Briefs were submitted in late Aug. and early Sept., and oral arguments were heard on 22 Sept. A transcript of the oral arguments is available at <http//www.un.org/icty/transe14/ 970922IT.txt> (visited 16 Feb. 2000).

83. Blaškić II, supra note 6, ๆl 23.

84. Id. I 21.

85. Id. T 25.

86. The Appeals Chamber differentiated between "inherent" and "implied" powers. The IC), the court found, used the implied powers doctrine "with a view to expanding the competencies of political organs of international organizations." Id. श 25 n.27 (emphasis in original (citing, inter alia, cases cited supra note 59). The concept of inherent powers was used to insure that "the exercise of [the IC]'s] jurisdiction over the merits, if and when established, shall not be frustrated, and ... to provide for the orderly settlement of all matters in dispute." Id. (quoting Nuclear Tests (Austl. v. Fr.), 1974 I.C.). 259-60, शा 23).

87. Id. II 25; ICTY Statute, supra note 11 , art. 29 ; S.C. Res. 827 , U.N. SCOR, 3217 th mtg., II 4, U.N. Doc. S/RES/827 (1993).

88. Blaškic II, supra note 6 , II 26. The court specified the content of the binding orders as follows: (1) "identify specific documents"; (2) "set out succinctly the reasons why such documents are deemed relevant to the trial"; (3) "not be unduly onerous"; (4) "give the requested State sufficient time for compliance[.]" Id. II 32.

89. Id. II 33. See also id. III 35-36 (setting out rules for judicial findings).

90. Id. ๆ 33. 
binding orders to state officials (though it could issue subpoenas to individuals acting in their private capacity)..$^{91}$

The Appeals Chamber decision was a clear rebuke of the Trial Chamber's conclusion and methodology. ${ }^{92}$ Taking into account the peculiar

91. Id. II 38-45 (state officials), 46-60 (individuals in their private capacity).

Upholding the Trial Chamber, the Appeals Chamber recognized that certain requested documents may be covered by a national security privilege, but the court (and not the state) was to decide whether the privilege applied. See id. II II 62-66 (discussing the Sabotage, Ballo, Godinez Cruz cases and Cyprus v. Turkey, as well as Article 2, paragraph 7, of the United Nations Charter). When deciding whether an assertion of national security is applicable, the court held that the Trial Chamber: (1) should take into account "whether the State concerned has acted and is acting bona fide[;]" (2) should have only one judge look at the relevant documents; (3) should have the state submit certified translations, if necessary; (4) should look at the documents in camera and ex parte; (5) should return the irrelevant or privileged documents to the state; and (6) should allow for certain extremely sensitive documents not to be submitted for scrutiny. Id. II 68. Judge Adolphus G. Karibi-Whyte wrote a separate opinion that took issue with items two and three of the court's national security procedures. See Separate Opinion of Judge Adolphus G. Karibi-Whyte, Prosecutor v. Blaškić, Case No. IT-95-14-AR1 08bis, App. Ch., II 4 (ICTY 29 Oct. 1997), available at <http:/www.un.org/ icty/blaskic/appeal/decision-e/71029JTK.html> (visited 16 Feb. 2000).

92. After the decision was handed down, the Office of the Prosecutor made the unconvincing claim that the Appeals Chamber had decided in its favor. Prosecutor Arbour described the Appeals Chamber decision as "a vindication of the prosecution's position," and promised to "seek a binding order for the production of [Croatian] documents." Croatia Wins Appeal Against UN Court Subpoena, ANP English News Bulletin, 30 Oct. 1997, available in Lexis, NEWS Library, ANPENG File. The decision, however, was far from what the prosecution had originally desired. The Office of the Prosecutor has since issued an "order" to Croatia in accordance with the Appeals Chamber ruling. See Order to the Republic of Croatia for the Production of Documents, Prosecutor v. Blaskic, Case No. ICTY-95-14-T, T. Ch. I (ICTY 21 July 1998), available at <http//www.un.org/icty/blaskic/trialc1/order-e/80721PN16152.htm> (visited 16 Feb. 2000 ). Croatia challenged the binding order on national security grounds. See Decision on the Notice of State Request for Review of Order on the Motion of the Prosecutor for the Issuance of a Binding Order on the Republic of Croatia for the Production of Documents and Request for Stay of Trial Chamber's Order of 30 January 1998, Prosecutor v. Blaškić, Case No. IT-95-14-T, App. Ch. (ICTY 26 Feb. 1998), available at $<$ http://www.un.org/icty/blaskic/appeal/decision-e/80226SD3.htm> (visited 16 Feb. 2000); Order for a Witness to Appear, Prosecutor v. Blaškić, Case No. IT-95-14-T, T. Ch. I (ICTY 5 Nov. 1998), available at <http//www.un.org/icty/blaskic/trialc1/order-e/ 81105WG16153.htm> (visited 16 Feb. 2000). Judge McDonald, in her capacity as president of the ICTY, has reported Croatia to the Security Council for noncompliance with Tribunal requests, though not the requests at issue in Blaškić. See War Crime Tribunal Reports Croatia to Security Council for "Non-Cooperation," Agence France Presse, 25 Aug. 1999, available in Lexis, NEWS Library, CURNWS File. Immediately after Blaškić was found guilty in March 2000, see supra note 6, Croatia said that it would release newly discovered documents that had been withheld by the regime of the late president of Croatia, Franjo Tudjman. The documents, Croatian officials asserted, will assist Blaškić in his appeal of the guilty verdict. See Croatia to Release Documents to Defend Bosnian Croat War Criminal, Acence France Presse, 6 Mar. 2000, available in Lexis, NEWS Library, CURNWS File. 
nature of international tribunals in general, and the ICTY in particular, ${ }^{93}$ the Appeals Chamber took a pragmatic approach to the subpoena question. The Chamber delicately balanced the need for an effective investigation with a realistic assessment of the means by which an ICTY investigation is likely to succeed.

\section{An Alternative Solution}

The Trial Chamber in its teleological approach to its judgment looked to national courts and their coercive powers, as well as to the $\mathrm{ICJ}$ and other international courts. Even assuming correct facts, ${ }^{94}$ the analogies were misplaced. The ICTY is not like the ICJ (where jurisdiction is consensual), nor is it like national courts (which are governed by constitutional documents or other fundamental political structures). The Trial Chamber's error, thus, was not in its desire to achieve a teleological end (that is, fair trials) but in its method of how best to get there. It was the Trial Chamber's erroneous approach that made the issue in Blaškic unnecessarily grand. ${ }^{95}$ Given the realities of world politics, the Appeals Chamber had no choice but to temper the lower court's ruling.

But instead of relying on Chapter VII of the UN Charter as the fount of the subpoena power, both courts might have found an alternative-and much less politically problematic_textual source in the treaty that ended the war in Bosnia: the General Framework Agreement for Peace in Bosnia and Herzegovina, signed by Bosnia and Herzegovina, Croatia, and the Federal Republic of Yugoslavia. Article IX of that Agreement states:

The Parties shall cooperate fully with all entities involved in implementation of this peace settlement, as described in the Annexes to this Agreement, or which

93. The court explicitly rebutted the prosecutor's and Trial Chamber's resort to the "domestic analogy" for their justification of the power to subpoena state officials; "The setting is totally different in the international community," the court noted. Blaškić II, supra note 6, II 40. The international community was without a "central government with the attendant separation of powers and checks and balances. ... [I]nternational courts, including the International Tribunal, do not make up a judicial branch of a central government." $I d$. The court continued: "The International Tribunal is an international criminal court constituting a novelty in the world community." Id. II 47.

94. While I have summarized the opinions of the Trial and Appeals Chambers, I have generally refrained from quibbling with their textual readings and factual assertions. It is enough to say that alternative readings and interpretations are possible, if not likely. I have foregone this type of critique primarily because I feel that it is beside the point; as I make clear in the body of this article, other considerations were more important to the outcome of Blaškić.

95. While the court has often relied on the ICTY Statute and Chapter VII of the UN Charter in its rulings, it is unclear why the Trial Chamber felt it necessary to make the extensive claim that it did in Blaškić. 
are otherwise authorized by the United Nations Security Council, pursuant to the obligation of all parties to cooperate in the Investigation and prosecution of war crimes and other violations of international humanitarian law. ${ }^{96}$

Croatia, as a signatory of the Agreement, therefore, would have been required to comply with a subpoena issued by the ICTY. While the Tribunal, under this reasoning, would still have been reliant on the Security Council for the enforcement of subpoenas, a broad precedent that might have put the Tribunal into conflict with its essential backers would have been avoided. At the same time, those states most reluctant to release evidence (like Croatia) would have been obligated to do so.

\section{BLAŠKIĆ AND THE ROME STATUTE}

\section{A. The Legacy of Blaškić}

The general subject of Blaškić-the extent and nature of state obligations to cooperate with an international tribunal-and the particular issue with which the case dealt-the duty to comply with prosecutorial requests for evidence-had already been under discussion in the ICC preparatory committee meetings well before Tihomir Blaškić was brought to The Hague. ${ }^{97}$ This being so, the Blaškić decisions quickly found their way into the debate surrounding the International Criminal Court. ${ }^{98}$

96. General Framework Agreement, supra note 10, at 90 .

97. See, e.g., Report of the Preparatory Committee on the Establishment of an International Criminal Court, U.N. GAOR, 51st Sess., II 310, U.N. Doc. A/51/22/1996/64 (1996) [hereinafter Preparatory Committee Report]; Report of the International Law Commission on the Work of Its Forty-Sixth Session 2 May-22 July 1994, U.N. GAOR, 49th Sess., Supp. No. 10, at 129-30, U.N. Doc. A/49/10 (1994); Rolling Text of Articles 51 and 52, Prep. Comm. on the Establishment of an Int'| Crim. Ct., Working Group on Int'l Co-operation and Judicial Assistance, U.N. Doc. AAC.249/1997/WG.5/CRP.2* (1997), available at <gopher-//gopher.igc.apc.org:70/00/orgs/icc/undocs/prepcom5/art5152.txt>; Report of the Intersessional Meeting from 19 to 30 Jan. 1998 in Zutphen, the Netherlands, art. 78, II 6 (visited 9 Feb. 2000) <gopher-//gopher.igc.apc.org:70/O./orgs/ icc/undocs/zutphen/part9.txt>; Report of the Preparatory Committee on the Establishment of an International Criminal Court, Addendum, Part One, Draft Statute for the International Criminal Court, U.N. Diplomatic Conf. of Plenopotentiaries on the Establishment of an Int'| Crim. Ct., arts. 54(4)(b), 85, 86(6), 90(2), U.N. Doc. AV CONF.183/2/Add.1, (1998).

98. See, e.g., American Bar Association, Resolution and Report Recommending the Establishment of an International Criminal Court (2 Feb. 1998) (visited 16 Feb. 2000) <gopher:/gopher.igc.apc.org:70/00/orgs/icc/ngodocs/abareport.298> (citing Blaškić). According to Amnesty International:

Although the Appeals Chamber in Blaskic decided that it had no power under Article 29 of the Statute ... to issue subpoenas to state officials to testify or to produce documents, nothing prevents states from collectively drafting a statute with a more effective procedure. Indeed, unless the court 
In Rome, at the diplomatic conference to establish an ICC, diplomats largely followed the spirit of the decision of the Blaškić Appeals Chamber. Article 93 of the Rome Statute begins with the general rule that "States Parties shall . . . comply with requests by the Court to provide ... [t]he provision of records and documents, including official records and documents[.] $]^{\prime \prime 99}$ The statute then provides for two exceptions. First, if compliance with the specific request is "prohibited in the requested State on the basis of an existing fundamental legal principle of general application, the requested State shall promptly consult with the Court to try to resolve the matter."100 If the state and the court cannot resolve the matter, "the Court shall modify the request as necessary." ${ }^{101}$ Second, there is a national security exception: "a State Party may deny a request for assistance, in whole or in part, only if the request concerns the production of any documents or disclosure of evidence which relates to its national security." 102 If the court is unsatisfied with the state's reasons, it may, in accordance with Article 87(7), "make a finding to that effect and refer the matter to the Assembly of States Parties or, where the Security Council referred the matter to the Court, to the Security Council." ${ }^{103}$ The drafters of the Rome Statute appear to have applied the Appeals Chamber decision in Blaškić to the ICC: the court can only make "requests" of States Parties; it can only make a finding of non-compliance should a state fail to comply; and any coercive measures against the non-complying state can only be taken by a group of states, namely the Assembly of States Parties or the Security Council.

has the power to compel subordinates in a chain of command it may well be impossible to prosecute superiors for responsibility.

Amnesty International, The International Criminal Court: Making the Right Choices-Part III: Ensuring Effective State Cooperation, Al Index: IOR 40/13/97, Nov. 1997, at 53, available at <http://www.amnesty.it/ailib/aipub/1997/IOR/14001397.htm> (visited 16 Feb. 2000). See also Commentary for the March-April Preparatory Committee Meeting, Huм. Ris. WATCH, Feb. 1998, at $\S E$, available at $<$ http://www.hrw.org/hrw/campaigns/ icc/icc0398.htm> (visited 16 Feb. 2000) ("Human Rights Watch strongly urges delegates to follow the guidance of the Trial Chamber ... in the case of the Prosecutor $v$. Tihomir Blaškić. . . ."). According to the Lawyers Committee on Human Rights: “The recent controversies surrounding the power of [ICTY] to order the testimony and the production of documentary evidence by states and state officials highlighted a fundamental problem in the exercise of international criminal jurisdiction." Lawyers Committee on Human Rights, Compliance with ICC Decisions (International Criminal Court Briefing Series, Vol. 1, No. 5, Nov. 1997) (visited 16 Feb. 2000) <http://www.lchr .org/icc/iccpap5.htm>.

99. Rome Statute, supra note 7, art. 93(1)(i) (emphasis added). Article 57(3)(a) gives the Pre-Trial Chamber, at the request of the prosecutor, the power to "issue such orders and warrants as may be required for the purposes of an investigation." Id. art. 57(3)(a).

100. Id. art. 93(3).

101. Id. (emphasis added). This exception seems to deal with the transfer of indicted persons or witnesses and not documents.

102. Id. art. 93(4).

103. Id. art. $87(7)$. 


\section{B. Evaluating Article 93}

For an ICC to operate effectively and to provide for fair trials it must be able to secure the cooperation of its state parties in the surrender of suspects and in the procurement of the witnesses and evidence necessary to the successful investigation and prosecution of the crimes within its jurisdiction. Does Article 93 of the Rome Statute do this?

It seems not. Article 93 (and its related articles) is highly deferential to the state parties: The court can make only "requests" (not even "binding orders," let alone "subpoenas") to states, and states have two mechanisms for escaping compliance. In the event that a state fails to comply with the request (a highly likely scenario if one of its own nationals is under investigation), the court can only make a finding of non-compliance and refer the matter to the Assembly of States Parties (or, when appropriate, the Security Council) for its consideration. In the Assembly or the Security Council, the matter surely will be subject to political considerations. If the matter under investigation is one where the major powers support the prosecution (such as in the former Yugoslavia), the procedure might work and the requisite political will might be garnered to exert sufficient pressure on the non-cooperating state. ${ }^{104}$ If, however, the non-complying state is politically or militarily powerful, it is unlikely that the Assembly or the Security Council would act. Thus, the court's investigatory powers would be uneven, varying according to the power of the state in question.

On the one hand, Article 93 acknowledges the reality of world politics. Even if a future court had subpoena powers and could find a powerful state, such as the United States (if it ever signed and ratified the Rome Statute), in contempt for non-compliance, it would be unlikely that such a finding would be complied with; instead, the court might look foolish because it lacked any mechanism to enforce its order. Even if the state was less powerful, the court would still need the support of the Assembly of States Parties to enforce any order it might make. On the other hand, and more importantly, if a future court is to be seen as anything more than the tool of the Assembly of States Parties, it must have some independence from that body and some means of distancing itself from politics. It is one thing to acknowledge the way the world works; it is quite another to concede that this is the way it ought to work.

The structural differences between the ICTY and the ICC are crucial to understanding why a broad subpoena power would be damaging to one but

104. While the Security Council, by virtue of its Chapter VII powers, has the authority to use force, it is unclear what coercive powers the Assembly of States Parties might legitimately use to ensure compliance with a court's order. 
essential to the other. The Security Council, under its Chapter VII powers, established the ICTY in order to prosecute war crimes within the former Yugoslavia. But the ICC was established in a different way and in a different context-by a multilateral treaty at an international diplomatic conference. All of those who ratify it will agree to its provisions. ${ }^{105}$ Consequently, an ICC treaty that included the subpoena power would be binding on its state parties by virtue of their ratifications in the same way that the General Framework Agreement for Peace in Bosnia and Herzegovina is binding on Bosnia and Herzegovina, Croatia, and the Federal Republic of Yugoslavia. While stronger judicial assistance provisions would probably have made it more difficult for states to ratify the treaty, it would have been preferable for states to be committed to a court that could accomplish its task than for them to sign on to a treaty that would be unable to achieve its objective. The diplomats in Rome had an opportunity to create an effective treaty, but instead (and unfortunately) they opted for a court that will lack some of the basic tools necessary for the performance of its functions.

\section{CONCLUSION: FAIR TRIALS IN INTERNATIONAL CRIMINAL COURTS?}

The creation of an international criminal court is a serious and perilous project. If it succeeds, the court will bring criminals to justice who, heretofore, have largely escaped international sanction. If it fails, the court could become a "kangaroo court" or it might simply dissolve into irrelevance. ${ }^{106}$ As one commentator has recently written, "The danger of failure is a mockery of international law giving impetus to those who suggest that it is not law at all!" 107 Similarly, Deputy Prosecutor Graham Blewitt has warned: "To raise such hopes but fail to fully implement the system of justice thus created is far worse, in my opinion, than having done nothing in the first place." 108

The diplomats in Rome could have taken one step toward an effective ICC if they had included provisions in the statute that would have given the court the ability to obtain the evidence necessary for fair trials. They might have learned more, in this regard, from the Trial Chamber decision than from the Appeals Chamber judgment. Though the parallels Judge McDonald

105. Reservations are prohibited. See Id. art. 120.

106. See Christopher L. Blakesley, Report of the International Law Association, 25 Denv. J. INT'L L. \& POL'Y 233, 234 (1997).

107. Id.

108. Power, supra note 45 (quoting Blewitt). 
and some of the amici ${ }^{109}$ drew to domestic subpoena powers were simplistic and overdone when applied to the ICTY, the teleological approach that the Trial Chamber pursued, when applied to the ICC, might have led to a more independent and effective court. The fact that the Rome diplomats were unable to solve the problem of obtaining evidence for fair trials in international criminal tribunals is cause for concern if and when an International Criminal Court finally comes into being.

109. See, e.g., Amicus Curiae Brief Submitted by the Max Planck Institute for Foreign and International Criminal Law, Freiburg im Breisgau, Germany, Prosecutor v. Blaskic, Case No. IT-95-14-AR108bis, App. Ch., II 49-50 (ICTY 15 Sept. 1997) (comparing the approach of national courts to the production of evidence and the limits on such powers and concluding that international courts should operate in substantially similar ways). 